\title{
PENYALAHGUNAAN WEWENANG KEPALA SATUAN KERJA PERANGKAT DAERAH DALAM PENETAPAN KINERJA DAN PENGELOLAAN KEUANGAN DAERAH
}

\section{JACOBUS RONALD MAWUNTU}

Dosen Fakultas Hukum Universitas Sam Ratulangi, Jalan Bahu Manado 95115, Telp. (0431) 866146, fax: 0431-825668. E-mail: psilmuhukum_pascaunsrat@yahoo.co.id.

\section{ABSTRAK}

Tulisan ini berisi tentang Penyalahgunaan Kekuasaan dalam menjaga, akuntabilitas, transparansi, dan laporan keuangan pemerintah. Pertama, Kepala Unit (SKPD) harus mampu mendistribusikan deskripsi pekerjaan untuk unit mereka dan membuat komitmen dengan Kepala Daerah untuk Penentuan Kinerja (Penetapan Kinerja) pada unitnya. Penetapan kinerja sebagai alat untuk perencanaan, untuk melaksanakan program dan menggunakan anggaran dengan APBD. Jika Kepala Unit (SKPD) tidak menentukan beban kerja kepada unit di bawahnya, SKPD telah melakukan Penyalahgunaan Kekuasaan. Kedua, tanpa penentuan kinerja, maka akan terjadi suatu perusakan sistem.

Kata kunci: Penyalahgunaan kekuasaan, Penentuan kinerja, Laporan keuangan pemerintah daerah.

\section{ABSTRACT}

This subject descript about Abuse of Power in maintaining, accountability, transparency and government financial report. First, Chief of Unit (SKPD) should be able to distribute job description for their units and make commitment with Chief of Region to Determination of Performance (Penetapan Kinerja) on his unit of works. Determination of performance as a tool to planning, to doing program and to use budgeting by APBD. If Chief of Unit (SKPD) have not determination of performance on job description for units of work, certainly the SKPD make Abuse of Power. Secondly, without determination of performance, it will be corrupt or disclaimer.

Keyword: Abuse of power, Determination of performance, Government financial report. 


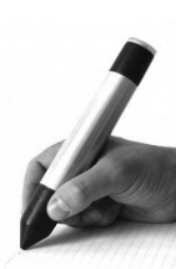

\section{PENDAHULUAN}

Pelimpahan kewenangan pemerintahan dari pusat ke daerah (desentralisasi), telah membawa bandul perubahan bagi tata kelola pemerintahan. Dampak perubahan otonomi daerah cukup besar dalam hal mengelola rumah tangga dan anggaran keuangan di setiap daerah provinsi/kabupaten/kota. Menurut Bagir Manan, otonomi daerah adalah kebebasan dan kemandirian (vrijheid en zelfstandigheid) untuk mengatur dan mengurus sebagian urusan pemerintahan. Kebebasan dan kemandirian mengandung arti atas nama dan tanggung jawab sendiri (op eigen naam en veranwoordelijkheid) (Hendra Karianga, 2011).

Kebebasan dan kemandirian yang dimiliki oleh daerah didasarkan pada undang-undang. Otonomi harus dapat dikelola dengan baik termasuk APBD. Pengelolaan APBD harus dilaksanakan tetap pada prinsip tata kelola keuangan yang baik (good financial governance) yakni mengedepankan partisipasi, transparansi, akuntabilitas, dan berkeadilan, dengan berorientasi pada hasil yang akan dicapai (output) dan manfaat yang dirasakan oleh masyarakat (benefit) (Hendra Karianga, $2011: 8-9)$. 


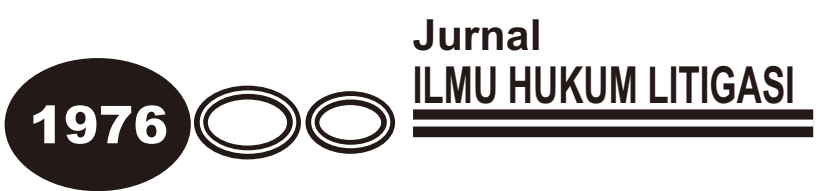

Secara konseptual, pengelolaan keuangan daerah merupakan rangkaian kegiatan yang dilakukan oleh pejabat pengelola keuangan daerah sesuai dengan kedudukan dan kewenangannya yang meliputi kegiatan perencanaan, pelaksanaan, pengawasan dan pertanggungjawaban. Perencanaan mengandung arti semua program pembangunan harus direncanakan dengan ketersediaan dana yang cukup, pelaksanaan anggaran bertujuan untuk mencapai visi, misi dan program pembangunan yang direncanakan, pertanggungjawaban mengandung arti pejabat pengelola anggaran harus dapat mempertanggungjawabkan pengelolaan anggaran dengan benar dan diterima oleh masyarakat (Hendra Karianga, $2011: 9)$.

Di lain pihak, kondisi otonomi daerah diwarnai dengan reformasi birokrasi maupun reformasi di bidang politik. Proses demokrasi prosedural dalam era desentralisasi menjadikan APBD sering dijadikan "lumbung anggaran partai" disertai berbagai kepentingan politik atau kerap kali dijadikan "mesin ATM $^{\prime \prime}$ bagi politisi maupun birokrat yang berkuasa. Fenomena tersebut berlangsung dan sampai saat ini masih dipraktikan, sehingga tidak jarang ada kandidat Gubernur/Bupati/Walikota diadili dan dihukum karena melakukan tindak pidana korupsi Anggaran Pendapatan dan Belanja Daerah. 
Tercatat, dari tahun 2004 hingga bulan September 2012, sebanyak 131 pejabat negara termasuk kepala daerah/wakil kepala daerah tersangkut kasus korupsi APBD dan sedang menjalani proses di pengadilan (www.mediaindonesia.com). Jika selama ini, anggapan umum abuse of power diartikan sebagai tindakan pejabat negara melakukan penyelewengan berupa korupsi dana APBD, hal tersebut memang tidak keliru. Abuse of Power dapat saja dilakukan oleh oknum pejabat negara sekaligus kepala daerah yang diserahi tanggung jawab tata kelola pemerintahan dan keuangan negara maupun keuangan daerah.

Akan tetapi dalam penulisan ini sebagaimana judul di atas, tindakan abuse of power yang akan dibahas tertuju pada pejabat negara setingkat Kepala Satuan Kerja Pemerintah Daerah (SKPD) terkait dengan Penetapan Kinerja. Jika Kepala SKPD tidak melakukan Penetapan Kinerja, maka akan berdampak luas dan sistemik pada penggunaan dan pengelolaan keuangan daerah, sehingga dapat menimbulkan kerugian bagi negara/daerah dan tentunya tidak mendatangkan manfaat bagi masyarakat. 


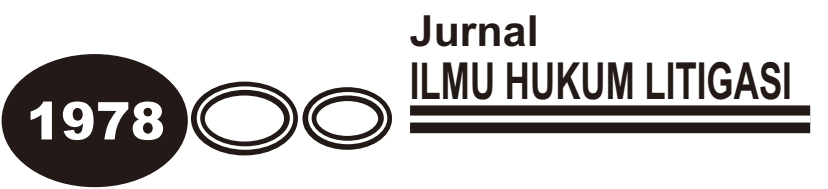

1. Bagaimana bentuk penyalahgunaan wewenang Kepala SKPD terkait Penetapan Kinerja?

2. Bagaimana bentuk penyalahgunaan wewenang Kepala SKPD terkait Pengelolaan Keuangan Daerah?

\section{METODE PENELITIAN}

Metode penelitian yang dilakukan dalam penulisan ini adalah metode penelitian normatif yang difokuskan untuk mengkaji wewenang pejabat negara (Kepala SKPD) dalam melakukan perencanaan, pelaksanaan, pengawasan dan pertanggungjawaban terhadap pengelolaan keuangan daerah. Bahan hukum primer adalah undang-undang dan peraturan-peraturan terkait Keuangan Negara dan Pengelolaan Keuangan Daerah.

Pendekatan yang digunakan dalam penelitian ini adalah metode yuridis normatif. Teknik pengumpulan dan analisis dilakukan melalui studi kepustakaan (library research) dengan pendekatan perundang-undangan. Adapun sumbersumber penulisan terdiri dari sumber primer yakni undang-undang atau peraturan terkait Keuangan Negara dan Pengelolaan Keuangan Daerah dan sumber sekunder berupa teks buku, jurnal-jurnal, wawancara dan laporan-laporan kertas kerja pemeriksaan (Peter, Mahmud, $2007: 12$ ). 
Dalam melakukan analisis terhadap tindakan penyalahgunaan wewenang Kepala SKPD, maka penulis melakukan pendekatan studi kasus (case studi) terkait laporan kertas kerja pemeriksaan dan Pengawasan Tupoksi Inspektorat Provinsi kepada Kepala SKPD selaku Penanggung Jawab Kinerja.

\section{HASIL PENELITIAN DAN ANALISIS}

A. Penyalahgunaan Kewenangan Kepala SKPD dalam Penetapan Kinerja

Kamus hukum abuse of power (abus de pouvoir) diartikan penyalahgunaan kekuasaan oleh instansi pemerintah (JCT, Simorangkir, 2002). Dalam bahasa Belanda dikenal Misbruik van Recht, yakni penyalahgunaan kekuasaan yang biasanya dilakukan oleh pejabat dalam ranah hukum Tata Usaha Negara misalnya tindakan dan keputusan pejabat yang bertentangan dengan peraturan yang berlaku dan mengakibatkan kerugian bagi pegawai di lingkungan pemerintahan.

Dalam penulisan ini abuse of power diartikan sebagai penyalahgunaan wewenang oleh pejabat pengelola keuangan daerah yang melakukan atau tidak melakukan tugas dan kewajibannya, sehingga akibat tindakannya tersebut daerah mengalami kerugian. 


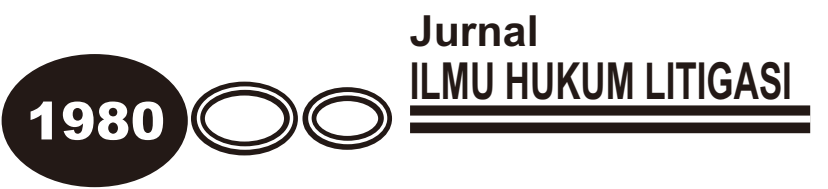

Undang-Undang Otonomi Daerah No. 32 Tahun 2004, membagi urusan wajib dan urusan pilihan yang dapat dilakukan Pemerintah Daerah untuk melaksanakan desentralisasi dan pembangunan di daerah. Urusan pemerintahan daerah tersebut, diejahwantahkan dalam bentuk struktur aparatur daerah berupa Dinas Perangkat Kerja yang mewakili urusan wajib dan urusan pilihan pemerintahan.

Selanjutnya, Pasal 21 mengamanatkan dalam hal penyelenggaraan Otonomi Daerah, daerah berhak mengatur sendiri urusan pemerintahannya. Hal ini terkait pula memilih pimpinan daerah dan mengelola aparatur daerah. Kepala Satuan Kerja Perangkat Daerah merupakan bagian daripada aparatur daerah yang berkewajiban melaksanakan urusan-urusan pemerintah daerah dan juga melekat tugas dan fungsi sebagaimana aturan Permendagri Nomor 13 Tahun 2006 yakni mendapatkan kekuasaan/kewenangan pengelolaan keuangan daerah yang telah didesentralisasikan tersebut.

Adapun skema desentralisasi menurut Permendagri Nomor 13 tahun 2006 dalam pelaksanaan kekuasaan pengelolaan keuangan daerah adalah sebagai berikut: 
1. Kepala SKPKD selaku pejabat pengelola keuangan daerah.

2. Kepala SKPD selaku pejabat pengguna anggaran/pengguna barang daerah.

3. Sekda selaku koordinator pengelola keuangan daerah.

Dengan demikian, Kepala SKPD yang dimaksud adalah Kepala SKPD selaku pejabat penguna anggaran/pengguna barang daerah, yang lazimnya dalam struktur perangkat daerah sebagai Kepala Dinas/Kepala Badan/Sekretariat Daerah/Sekretariat DPRD.

Peraturan Menteri Negara Pendayagunaan Aparatur Negara dan Reformasi Birokrasi Nomor 29 Tahun 2010 tentang Pedoman Penyusunan Penetapan Kinerja dan Pelaporan Akuntabilitas Kinerja Instansi Pemerintah, antara lain ditegaskan dalam:

Pasal 3,

Dokumen Penetapan Kinerja merupakan suatu dokumen pernyataan/ kesepakatan / perjanjian kinerja antara atasan dan bawahan untuk mewujudkan target kinerja tertentu berdasarkan sumber daya yang dimiliki oleh instansi. 


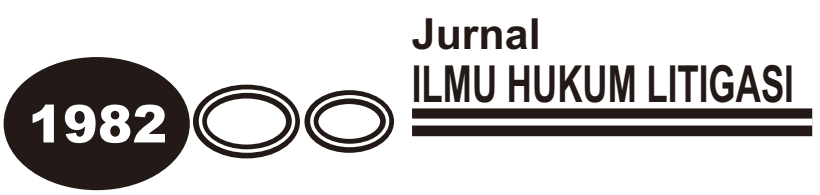

Bahwa dalam pelaksanaan dan pengelolaan pelayanan publik, setiap pejabat negara harus melakukan Penetapan Kinerja. Penetapan kinerja adalah komitmen antara Kepala SKPD dengan Kepala Daerah. Kinerja bagian dari tugas pokok dan fungsi. Penyelewengan dari SKPD dapat terjadi dalam pelaksanaan tugas pokok dan fungsi berupa pengelolaan kinerja yang kurang baik.

Dalam kertas kerja, tercatat bahwa Tim Pemeriksa melakukan pemeriksaan tanggal 8-9 Oktober 2012 di lingkungan Dinas X, Kota Y ditemukan 8 program dan 28 kegiatan dengan total anggaran sebesar Rp. 4.479.324.150,- tanpa Penetapan Kinerja Tahun 2012 yang merupakan suatu dokumen pernyataan kinerja/kesepakatan kerja/perjanjian kinerja tertentu berdasarkan pada sumber daya yang dimiliki oleh instansi dan/atau bagaimana dari tugas kedinasan dengan perincian sebagai berikut:

\begin{tabular}{|c|c|c|c|c|}
\hline No. & Sumber Dana & $\begin{array}{c}\text { Jumlah } \\
\text { Program }\end{array}$ & $\begin{array}{c}\text { Jumlah } \\
\text { Kegiatan }\end{array}$ & Anggaran \\
\hline 1. & APBD & 8 Program & 28 Kegiatan & 4.479 .342 .150 \\
\hline
\end{tabular}


Kondisi tersebut tidak sesuai dengan:

1. Peraturan Pemerintah Republik Indonesia Nomor 53 Tahun 2010, tentang Disiplin Pegawai Negeri Sipil, antara lain ditegaskan dalam:

a. Pasal 3 angka 5,

Setiap PNS wajib melaksanakan tugas kedinasan yang dipercayakan pada PNS dengan penuh pengabdian, kesadaran dan tanggung jawab.

b. Pasal 3 angka 9,

Setiap PNS wajib antara lain bekerja tertib dan cermat untuk kepentingan negara.

2. Peraturan Menteri Negara Pendayagunaan Aparatur Negara dan Reformasi Birokrasi Nomor 29 Tahun 2010 tentang Pedoman Penyusunan Penetapan Kinerja dan Pelaporan Akuntabilitas Kinerja Instansi Pemerintah, antara lain ditegaskan dalam:

a. Pasal 3,

Dokumen Penetapan Kinerja merupakan suatu dokumen pernyataan/ kesepakatan / perjanjian kinerja antara atasan dan bawahan untuk mewujudkan target kinerja tertentu berdasarkan sumber daya yang dimiliki oleh instansi. 


\section{Jurnal

b. Pasal 4 ayat (3),

Satuan kerja dan unit kerja Eselon II menyusun penetapan kinerja setelah menerima dokumen pelaksanaan anggaran dan ditandatangani oleh pimpinan unit organisasi dan pimpinan satuan kerja.

c. Pasal 5 ayat (1),

Pemerintah provinsi/kabupaten/kota menyusun dokumen penetapan kinerja setelah menerima dokumen pelaksanaan dan ditandatangani oleh Gubernur/Bupati/Walikota dan pimpinan SKPD/unit kerja mandiri.

Adapun Penilaian Tim Pemeriksa, bahwa:

a. hal ini disebabkan kelalaian pejabat pengelola yang kurang tertib dan cermat dalam melaksanakan sebagian tugas kedinasan berupa belum/tidak menyusun, membuat dan melakukan koordinasi dengan instansi terkait dalam rangka penyelesaian penetapan kinerja tahun 2012 untuk Dinas X di Kota Y.

b. Akibat dari butir a tersebut di atas, dapat mempengaruhi monitoring dan evaluasi terhadap seluruh program dan kegiatan menurut tujuan, sasaran dan target oleh Kepala Daerah kepada Kepala SKPD yang 
bersangkutan, termasuk mempengaruhi penyusunan Laporan Akuntabilitas Kinerja Instansi Pemerintah Tahunan.

B. Penyalahgunaan Kewenangan Kepala SKPD dalam Pengelolaan Keuangan Daerah

Sebagaimana skema desentralisasi menurut Permendagri Nomor 13 tahun 2006 dalam pelaksanaan kekuasaan pengelolaan keuangan daerah, Sekretaris Daerah membantu Kepala Daerah menyusun kebijakan dan mengkoordinasikan penyelenggaraan urusan Pemerintah Daerah termasuk pengelolaan keuangan daerah. Sedangkan Kepala SKPD selaku pejabat pengguna anggaran/pengguna barang daerah berdasarkan prinsip pemisahan kewenangan, dalam melaksanakan fungsinya selaku PPA bertugas, sebagai berikut:

1. Menyusun Rencana Kerja Anggaran dan DPA-SKPD

2. Melakukan tindakan yang mengakibatkan pengeluaran atas beban belanja

3. Melaksanakan anggaran SKPD

4. Mengelola barang milik daerah/kekayaan daerah yang menjadi tangggung jawab SKPD yang dipimpinnya.

5. Menyusun dan menyampaikan laporan keuangan SKPD 


\section{6 \\ Jurnal}

6. Mengawasi pelaksanaan anggaran SKPD

7. Melaksanakan tugas-tugas Pengguna Anggaran/Pengguna Barang lainnya berdasarkan kuasa yang dilimpahkan Kepala Daerah.

Disebutkan dalam laporan bahwa Tim Pemeriksa melakukan pemeriksaan tanggal 8-9 Oktober 2012 di lingkungan Dinas $\mathrm{X}$, Kota Y ditemukan 8 program dan 28 kegiatan dengan total anggaran sebesar Rp. 4.479.324.150,- Tahun Anggaran 2012 tanpa bukti laporan tertulis (triwulan/semester) oleh Pejabat Pembuat Komitmen (PPK) dan Pejabat Pelaksana Teknis Kegiatan (PPTK) kepada SKPD selaku Pengguna Anggaran dan/atau bagian dari tugas kedinasan, dengan perincian sebagai berikut:

\begin{tabular}{|c|l|l|l|l|}
\hline No. & \multicolumn{1}{|c|}{$\begin{array}{c}\text { Nama Pejabat } \\
\text { Pembuat } \\
\text { Komitmen (PPK) } \\
\text { dan Pejabat } \\
\text { Pelaksana Kegiatan } \\
\text { (PPTK) }\end{array}$} & $\begin{array}{c}\text { Jumlah } \\
\text { Program }\end{array}$ & $\begin{array}{c}\text { Jumlah } \\
\text { Kegiatan }\end{array}$ & Anggaran \\
\hline 1. & $\begin{array}{l}\text { ABE } \\
\text { (Kepala SKPD) } \\
\text { ROSA } \\
\text { (Sekretaris Dinas) }\end{array}$ & $\begin{array}{c}\text { 8 Program } \\
\text { 8 Program }\end{array}$ & $\begin{array}{c}28 \text { Kegiatan } \\
28 \text { kegiatan }\end{array}$ & $\begin{array}{c}\text { Rp.4.479.3479.342.150 } \\
\text { Rp.450 }\end{array}$ \\
\hline
\end{tabular}


Kondisi tersebut tidak sesuai dengan:

1. Peraturan Pemerintah Republik Indonesia Nomor 53 Tahun 2010, tentang Disiplin Pegawai Negeri Sipil, antara lain ditegaskan dalam:

a. Pasal 3 angka 5 ,

Setiap PNS wajib melaksanakan tugas kedinasan yang dipercayakan pada PNS dengan penuh pengabdian, kesadaran dan tanggung jawab.

b. Pasal 3 angka 9,

Setiap PNS wajib antara lain bekerja tertib dan cermat untuk kepentingan negara.

2. Peraturan Pemerintah Republik Indonesia Nomor 54 Tahun 2010, tentang Pengadaan Barang/Jasa Pemerintah, antara lain ditegaskan:

a. Pasal 1 angka 5,

Pengguna Anggaran yang selanjutnya disebut PA adalah Pejabat pemegang kewenangan penggunaan anggaran Kementerian/Lembaga/ Satuan Kerja Perangkat Daerah atau pejabat yang disamakan pada institusi lain Pengguna APBN/APBD. 


\section{8 \\ Jurnal \\ ILMU HUKUM LITIGASI}

b. Pasal 1 angka 7,

Pejabat pembuat komitmen yang selanjutnya disebut PPK adalah pejabat yang bertanggungjawab atas pelaksanaan Pengadaan Barang/]asa.

c. Pasal 6 huruf a,

Melaksanakan secara tertib, disertai rasa tanggung jawab untuk mencapai sasaran, kelancaran tercapainya tujuan pengadaan Barang/Jasa.

d. Pasal 11 ayat 1 huruf $h$,

PPK memiliki tugas pokok dan kewenangan antara lain melaporkan kemajuan pekerjaan termasuk penyerapan anggaran dan hambatan pelaksanaan kepada PA/KPA setiap triwulan.

3. Peraturan Menteri Dalam Negeri Nomor 13 Tahun 2006 tentang Pedoman Pengelolaan Keuangan Daerah, antara lain ditegaskan dalam:

a. Pasal 12 ayat (1): Pejabat Pengguna Anggaran/Kuasa Pengguna Anggaran / Kuasa Pengguna barang dalam melaksanakan program dan kegiatan menunjuk Pejabat pada unit kerja SKPD selaku PPTK.

b. Pasal 12 ayat (3): PPTK yang ditunjuk oleh pengguna anggaran/pengguna barang sebagaimana dimaksud pada ayat (1) 
bertanggungjawab atas pelaksanaan tugasnya kepada Pengguna Anggaran/Pengguna Barang.

4. Negara Pendayagunaan Aparatur Negara dan Reformasi Birokrasi Nomor 29 Tahun 2010 tentang Pedoman Penyusunan Penetapan Kinerja dan Pelaporan Akuntabilitas Kinerja Instansi Pemerintah, antara lain ditegaskan dalam:

a. Pasal 3

Dokumen Penetapan Kinerja merupakan suatu dokumen pernyataan/kesepakatan/perjanjian kinerja antara atasan dan bawahan untuk mewujudkan target kinerja tertentu berdasarkan sumber daya yang dimiliki oleh instansi.

b. Pasal 4 ayat (3),

Satuan kerja dan unit kerja Eselon II menyusun penetapan kinerja setelah menerima dokumen pelaksanaan anggaran dan ditandatangani oleh pimpinan unit organisasi dan pimpinan satuan kerja.

c. Pasal 5 ayat (1),

Pemerintah provinsi/kabupaten/kota menyusun dokumen penetapan kinerja setelah menerima dokumen pelaksanaan dan ditandatangani 


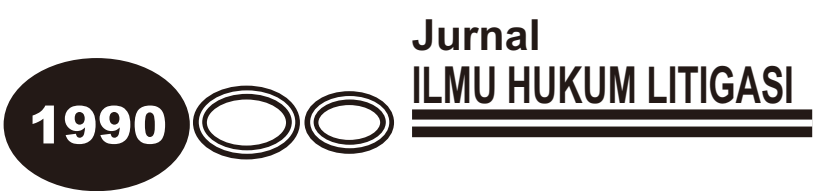

oleh Gubernur/Bupati/Walikota dan pimpinan SKPD/unit kerja mandiri.

Adapun Penilaian Tim Pemeriksa, bahwa:

a. Hal ini disebabkan kelalaian pejabat pengelola yang kurang tertib dan cermat dalam melaksanakan sebagian tugas kedinasan berupa belum/tidak menyusun, membuat dan melakukan koordinasi dengan instansi terkait dalam rangka penyelesaian penetapan kinerja tahun 2012 untuk Dinas X di Kota Y.

b. Akibatnya, dapat mempengaruhi monitoring dan evaluasi terhadap seluruh program dan kegiatan menurut tujuan, sasaran dan target oleh Kepala Daerah kepada Kepala SKPD yang bersangkutan, termasuk mempengaruhi penyusunan Laporan Akuntabilitas Kinerja Instansi Pemerintah Tahunan. 


\section{SIMPULAN DAN SARAN}

A. Simpulan

Abuse of Power dapat diartikan melaksanakan atau tidak melaksanakan amanat peraturan dan perundang-undangan, yang membawa dampak / mengakibatkan seorang Kepala SKPD melakukan penyalahgunaan wewenang, sebagai berikut:

a. Bentuk penyalahgunaan wewenang Kepala SKPD dapat terjadi ketika Kepala SKPD tidak melakukan Penetapan Kinerja sebagaimana Peraturan Menteri Negara Pendayagunaan Aparatur Negara dan Reformasi Birokrasi Nomor 29 Tahun 2010 tentang Pedoman Penyusunan Penetapan Kinerja dan Pelaporan Akuntabilitas Kinerja Instansi Pemerintah.

b. Ketika Penetapan Kinerja tidak dilakukan oleh Kepala SKPD maka secara langsung mempengaruhi pengelolaan keuangan daerah sebagaimana amanat Peraturan Menteri Dalam Negeri Nomor 13 Tahun 2006 tentang Pedoman Pengelolaan Keuangan Daerah. 


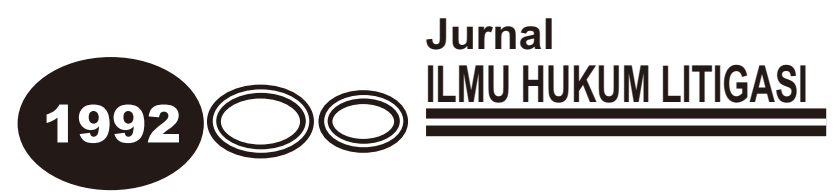

B. Saran

Dalam melakukan tindakan sebagai Pejabat/Kepala SKPD, hendaknya menerapkan azas koordinasi, cermat, kehati-hatiaan dalam mengambil keputusan baik terkait Penetapan Kinerja dan Pengelolaan Keuangan Daerah. 


\section{DAFTAR PUSTAKA}

Hendra Karianga, 2011, Partisipasi Masyarakat dalam Pengelolaan Keuangan Daerah Perspektif Hukum dan Demokrasi, Bandung, Alumni.

JCT. Simorangkir, 2002, Kamus Hukum, Jakarta, Sinar Grafika.

Tim Pemeriksa Inspektorat Provinsi Sulut, Kertas Kerja Laporan Tim Pemeriksa Inspektorat Provinsi Sulut Tahun 2012.

\section{JURNAL}

Peter Mahmud 2007, dalam Frans Kalesaran, Jurnal Ilmiah Hukum Servanda vol 5 No. 4, Oktober 201 1, Manado, Unika De La Salle.

\section{WEBSITE}

Medialndonesia.com, Kejaksaan masih Berdalih untuk periksa Kepala Daerah. diakses 2 Oktober 2012.

\section{PERATURAN PERUNDANGAN}

Undang-Undang Republik Indonesia Nomor 17 Tahun 2003 tentang Keuangan Negara.

Undang-Undang No. 1 Tahun 2004 tentang Perbendaharaan Negara. 


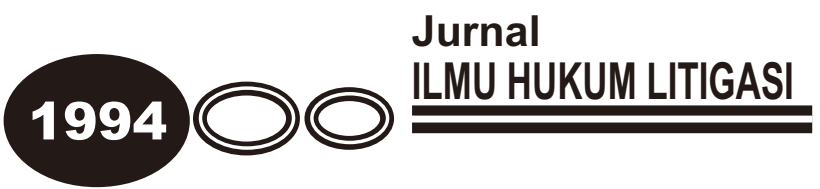

Peraturan Pemerintah Republik Indonesia Nomor 58 Tahun 2005 tentang Pengelolaan Keuangan Daerah.

Peraturan Pemerintah Republik Indonesia Nomor 53 Tahun 2010, tentang Disiplin Pegawai Negeri Sipil.

Peraturan Pemerintah Republik Indonesia Nomor 54 Tahun 2010, tentang Pengadaan Barang/Jasa Pemerintah.

Peraturan Menteri Negara Pendayagunaan Aparatur Negara dan Reformasi Birokrasi Nomor 29 Tahun 2010 tentang Pedoman Penyusunan Penetapan Kinerja dan Pelaporan Akuntabilitas Kinerja Instansi Pemerintah.

Peraturan Menteri Dalam Negeri Nomor 13 Tahun 2006 tentang Pedoman Pengelolaan Keuangan Daerah jo Peraturan Menteri Dalam Negeri Nomor 21 tahun 2011 tentang Pedoman Pengelolaan Keuangan Daerah. 